\title{
Bioactivities of Malvaviscus arboreus var. drummondii and Phyllanthus reticulatus Poir.
}

\section{Zokhroof Yeasmin ${ }^{1}$, Sharif Tanvir ${ }^{1}$, Tasnuva Sharmin ${ }^{2}$, Ridwan Bin Rashid ${ }^{3}$, Md. Al Amin Sikder ${ }^{2}$ and Mohammad A. Rashid ${ }^{2}$}

\author{
${ }^{1}$ Department of Pharmacy, State University of Bangladesh, Dhaka-1207, Bangladesh \\ ${ }^{2}$ Department of Pharmaceutical Chemistry, Faculty of Pharmacy, University of Dhaka, \\ Dhaka-1000, Bangladesh \\ ${ }^{3}$ Department of Microbiology, University of Dhaka, Dhaka-1000, Bangladesh
}

Received: April 16, 2014; Accepted: August 11, 2014; Published (web): October 13, 2014

\begin{abstract}
The study was designed to evaluate the bioactivities of crude methanol extracts of leaves of Malvaviscus arboreus and Phyllanthus reticulatus along with their pet-ether, carbon tetrachloride, chloroform and aqueous soluble partitionates. The antioxidant potential was evaluated by DPPH and Folin-Ciocalteau reagents using butylated hydroxytolune (BHT) and ascorbic acid as standards. In the DPPH free radical scavenging assay, the crude methanol extract of $M$. arboreus revealed the highest free radical scavenging activity with $\mathrm{IC}_{50}$ values $6.47 \pm 0.78 \mu \mathrm{g} / \mathrm{ml}$. In brine shrimp lethality bioassay, the chloroform soluble materials of $M$. arboreus displayed the highest cytotoxic potential having $\mathrm{LC}_{50}$ values $2.73 \pm 0.36 \mu \mathrm{g} / \mathrm{ml}$, whereas the standard vincristine sulphate exhibited an $\mathrm{LC}_{50}$ value of $0.45 \mu \mathrm{g} / \mathrm{ml}$. In the thrombolytic activity assay, the pet-ether soluble fractions of $M$. arboreus and P. reticulatus revealed $55.60 \pm$ $0.48 \%$ and $18.99 \pm 0.84 \%$ clot lysis, respectively. In the membrane stabilizing activity assay, the chloroform soluble fraction of $M$. arboreus inhibited heat- and hypotonic solution- induced haemolysis of RBCs by $54.60 \pm 0.81 \%$ and $66.96 \pm 0.84 \%$ as compared to $57.06 \%$ and $72.79 \%$ inhibition by acetyl salicylic acid $(0.10 \mathrm{mg} / \mathrm{ml})$, respectively. On the other hand, the pet-ether soluble materials of crude methanol extract of P. reticulatus demonstrated $57.11 \pm 0.57 \%$ and $70.62 \pm 0.22 \%$ inhibition of heat- and hypotonic solution- induced hemolysis, respectively.
\end{abstract}

Key words: Malvaviscus arboreus, Phyllanthus reticulatus, antioxidant, DPPH, cytotoxicity, thrombolysis, membrane stabilization

\section{INTRODUCTION}

According to the World Health Organization (WHO), $80 \%$ of the world's populations rely on traditional medicines. ${ }^{1}$ The practice of herbal medicines is common in rural areas where western medicines are either too expensive or not available. ${ }^{1}$ Plants have been used frequently to treat common infectious diseases and some of these traditional medicines are still in use. It has been reported that 115 articles were published on the antimicrobial activity of medicinal plants in Pubmed during the period between 1966 and 1994, but in the following decade, between 1995 and 2004, 307 were published. ${ }^{2}$ The demand for more and more drugs

Correspondence to: Mohammad A. Rashid Tel.: +880-2-9661900, Extn.- 8137; Fax: +880-2-9667222; E-mail: rashidma@du.ac.bd

Dhaka Univ. J. Pharm. Sci. 13(2): 143-147, 2014 (December) from plant sources is increasing and therefore it is essential for systematic evaluation of plants used in traditional medicines. Drugs derived from unmodified natural products or drugs semisynthetically obtained from natural sources correspond to $78 \%$ of the new drugs approved by the FDA between 1983 and 1994. ${ }^{3}$ Hence, there is need to screen medicinal plants with promising biological activity. ${ }^{4}$

Malvaviscus arboreus var. drummondii (Synonyms: Malvaviscus balbisii DC., Hibiscus malvaviscus L. Bengali name: Lanka jaba) belongs to the hibiscus family, Malvaceae. It is a species of the flowering plants that is native to the Southeastern United States, Mexico and Central and South America. Liniment made from the base of 
the plant is used for dressing burns. The leaf paste is applied and rubbed in the burnt area. ${ }^{5}$

Phyllanthus reticulatus Poir. (Synonyms: Anisonema reticulatum Poir. A. Juss., Cicca reticulata Poir. Kurz.; Bengali name: Panjuli, Panseuli, Chitki, Pankushi) belonging to the family Euphorbiceae, is a large often scandent shrub. It grows throughout the country in fallow lands. The fruits have been reported to exhibit antiinflammatory activity. ${ }^{6}$ Crude methanol extract of the whole plant possesses free radical scavenging activity. ${ }^{7}$ Its leaf and stem have been reported to contain lupeol. ${ }^{8}$ A new purine derivative, 3-(3methylbut-2-en-1-yl) isoguanine and a new cleistanthane-type diterpenoid glucoside, 19hydroxyspruceanol 19-O- $\beta$-D-glucopyranoside, together with eight known compounds have been isolated from $P$. reticulates. ${ }^{9}$

As part of our ongoing investigations on medicinal plants of Bangladesh ${ }^{10-12}$, the extractives of leaves of $M$. arboreus were screened for the antioxidant potential in terms of total phenolic content and free radical scavenging activities; cytotoxic, thrombolytic and membrane stabilizing activities whereas the extractives of $P$. reticulatus were studied for thrombolytic and membrane stabilizing activities for the first time and we, here in, report the results of our preliminary investigations.

\section{MATERIALS AND METHODS}

Collection of plant materials and extraction. The leaves of $M$. arboreus and $P$. reticulatus were collected in March 2012 from National Botanical Garden, Mirpur, Dhaka and voucher specimens (DUSH-10780 and DUSH-10781, respectively) for these collections have been maintained in Dhaka University Salar Khan Herbarium for future references.

The collected plant materials were cleaned, sun dried and pulverized. The powdered materials (500 gm each) of both the plants were separately soaked in 2.0 liters of methanol at room temperature for 7 days. The extracts were filtered through fresh cotton bed and finally with Whatman filter paper number 1 . The filtrates were concentrated with a rotary evaporator at reduced temperature and pressure. An aliquot (5 gm) of each of the concentrated methanol extract was fractionated by the modified Kupchan partitioning protocol $^{13}$ and the resultant partitionates were evaporated to dryness with a rotary evaporator to yield pet-ether (PESF), carbon tetrachloride (CTCSF), chloroform (CSF) and aqueous (AQSF) soluble materials (Table 1). The residues were then stored in a refrigerator until further use.

Table 1. Kupchan partitionates of $M$. arboreus and $P$. reticulatus.

\begin{tabular}{ccc}
\hline $\begin{array}{c}\text { Crude extract/ } \\
\text { Fraction }\end{array}$ & $\begin{array}{c}\text { M. arboreus } \\
(\mathrm{gm})\end{array}$ & $\begin{array}{c}\text { P. reticulatus } \\
(\mathrm{gm})\end{array}$ \\
\hline ME & 5.0 & 5.0 \\
PESF & 0.5 & 1.0 \\
CTCSF & 1.5 & 1.5 \\
CSF & 1.0 & 0.5 \\
AQSF & 1.5 & 1.3 \\
\hline
\end{tabular}

$\mathrm{ME}=$ Methanolic crude extract; $\mathrm{PESF}=$ Pet-ether soluble fraction; $\mathrm{CTCSF}=$ Carbon tetrachloride soluble fraction; $\mathrm{CSF}=$ Chloroform soluble fraction; AQSF= Aqueous soluble fraction.

DPPH free radical scavenging assay. Following the method developed by Brand-Williams et al. ${ }^{15}$, the antioxidant activity of the test samples was assessed by evaluating the scavenging of stable 1, 1-diphenyl2-picrylhydrazyl (DPPH) free radical by using synthetic antioxidants, butylated hydroxytoluene (BHT) and ascorbic acid as positive controls.

Total phenolic content. The total phenolic content of the extractives was determined with FolinCiocalteau reagent by using the method developed by Harbertson and Spayd (2006). ${ }^{14}$

Brine shrimp lethality bioassay. This was applied for the determination of general toxic properties of dimethylsulfoxide (DMSO) solution of plant extractives against Artemia salina in a one day assay. ${ }^{16}$ Vincristine sulphate was used as positive control.

Thrombolytic activity. The method developed by Prasad et al. ${ }^{17}$ was used to determine the thombolytic activity where streptokinase (SK) was used as positive control.

Membrane stabilizing activity. Inhibition of heat and hypotonic solution-induced haemolysis of human erythrocytes by the extractives was used to 
Table 2. Total phenolic content, free radical scavenging and cytotoxic activities of $M$. arboreus.

\begin{tabular}{ccccc}
\hline Plants & $\begin{array}{c}\text { Samples/ } \\
\text { Standards }\end{array}$ & $\begin{array}{c}\text { Total phenolic content } \\
\text { (mg of GAE/gm of } \\
\text { extract) }\end{array}$ & $\begin{array}{c}\text { DPPH Free radical } \\
\text { scavenging activity } \\
\left(\mathrm{IC}_{50} \mu \mathrm{g} / \mathrm{ml}\right)\end{array}$ & $\begin{array}{c}\text { Cytotoxicity }\left(\mathrm{LC}_{50}\right. \\
\mu \mathrm{g} / \mathrm{ml})\end{array}$ \\
\hline M. arboreus & ME & $20.06 \pm 0.87$ & $6.47 \pm 0.78$ & $3.82 \pm 0.08$ \\
& PESF & $0.13 \pm 0.09$ & $42.19 \pm 0.25$ & $28.46 \pm 0.19$ \\
& CTCSF & $18.13 \pm 0.27$ & $11.44 \pm 0.14$ & $53.97 \pm 0.54$ \\
& CSF & $18.38 \pm 0.65$ & $10.73 \pm 0.88$ & $2.73 \pm 0.36$ \\
& AQSF & $12.50 \pm 0.81$ & $11.59 \pm 0.57$ & $4.86 \pm 0.68$ \\
\hline VS & - & $27.50 \pm 0.54$ & 0.45 \\
& BHT & - & $5.80 \pm 0.21$ & - \\
\hline
\end{tabular}

$\mathrm{ME}=$ Methanolic crude extract; $\mathrm{PESF}=$ Pet-ether soluble fraction; $\mathrm{CTCSF}=\mathrm{Carbon}$ tetrachloride soluble fraction; $\mathrm{CSF}=\mathrm{Chloroform}$ soluble fraction; $\mathrm{AQSF}=$ Aqueous soluble fraction; $\mathrm{BHT}=$ Butylated hydroxytolune; $\mathrm{VS}=$ Vincristine sulfate.

Table 3. Thrombolytic activity of $M$. arboreus and $P$. reticulatus extractives.

\begin{tabular}{|c|c|c|}
\hline \multirow{2}{*}{ Sample } & \multicolumn{2}{|c|}{ Clot lysis } \\
\hline & M. arboreus & P. reticulatus \\
\hline $\mathrm{ME}$ & $12.99 \pm 0.19$ & $4.82 \pm 0.17$ \\
\hline PESF & $55.60 \pm 0.48$ & $18.99 \pm 0.84$ \\
\hline CTCSF & $18.74 \pm 0.56$ & $15.98 \pm 0.23$ \\
\hline $\mathrm{CSF}$ & $42.33 \pm 0.11$ & $9.30 \pm 0.45$ \\
\hline AQSF & $20.69 \pm 0.87$ & $17.89 \pm 0.88$ \\
\hline Water & & \\
\hline
\end{tabular}

SK = Streptokinase (Positive control); Water (negative control)

Table 4. Percentage inhibition of hypotonic solution and heat- induced hemolysis of RBC by M. arboreus and $P$. reticulatus extractives.

\begin{tabular}{|c|c|c|c|c|}
\hline \multirow[b]{3}{*}{ Sample } & \multicolumn{4}{|c|}{$\%$ Inhibition of haemolysis } \\
\hline & \multicolumn{2}{|c|}{ M. arboreus } & \multicolumn{2}{|c|}{ P. reticulatus } \\
\hline & $\begin{array}{c}\text { Hypnotic solution- } \\
\text { induced }\end{array}$ & Heat-induced & Hypnotic solution-induced & Heat-induced \\
\hline $\mathrm{ME}$ & $54.26 \pm 0.84$ & $47.62 \pm 0.21$ & $42.09 \pm 0.15$ & $47.65 \pm 0.28$ \\
\hline PESF & $64.97 \pm 0.23$ & $49.00 \pm 0.27$ & $70.62 \pm 0.22$ & $57.11 \pm 0.57$ \\
\hline CTCSF & $50.28 \pm 0.26$ & $39.56 \pm 0.43$ & $41.56 \pm 0.42$ & $40.86 \pm 0.39$ \\
\hline CSF & $66.96 \pm 0.84$ & $54.60 \pm 0.81$ & $43.65 \pm 0.74$ & $50.51 \pm 0.37$ \\
\hline AQSF & $53.20 \pm 0.84$ & $45.31 \pm 0.53$ & $47.77 \pm 0.36$ & $51.28 \pm 0.52$ \\
\hline Acetyl salicylic acid & $72.79 \pm 0.47$ & $57.06 \pm 0.23$ & $72.79 \pm 0.47$ & $57.06 \pm 0.23$ \\
\hline
\end{tabular}

assess the membrane stabilizing activity by a previously developed method. ${ }^{18}$

Statistical analysis. For all bioassays, three replicates of each sample were used for statistical analysis and the values are reported as mean $\pm \mathrm{SD}$.

\section{RESULTS AND DISCUSSION}

The extractives of leaves of $M$. arboreus were studied for antioxidant, cytotoxic, thrombolytic and membrane stabilizing activities whereas that of $P$. reticulatus were subjected to assays for thrombolytic and membrane stabilizing properties.
The total phenolic content of the samples of $M$. arboreus was found in the range of 0.13 to $20.06 \mathrm{mg}$ of GAE/g of extractives, with the highest amount of phenolic compounds (20.06 $\pm 0.87 \mathrm{mg})$ being observed in the crude methanol extract (Table 2). As the phenoics are relatively polar in nature, thus their presence in the methanol extract is justified.

In the DPPH free radical scavenging assay, the crude methanol extract of leaves of $M$. arboreus revealed maximum free radical scavenging activity $\left(\mathrm{IC}_{50}=6.47 \pm 0.78 \mu \mathrm{g} / \mathrm{ml}\right)$ when compared to ascorbic acid $\left(\mathrm{IC}_{50}=5.80 \pm 0.21 \mu \mathrm{g} / \mathrm{ml}\right)$ (Table 2). 
In the brine shrimp lethality bioassay, the chloroform soluble materials of $M$. arboreus displayed the highest cytotoxic potential having $\mathrm{LC}_{50}$ value $2.73 \pm 0.36 \mu \mathrm{g} / \mathrm{ml}$ as compared to $0.45 \mu \mathrm{g} / \mathrm{ml}$ for the standard vincristine sulphate. This suggested the presence of potent bioactive components in the above mentioned test sample (Table 2).

The extractives of $M$. arboreus and $P$. reticulatus were assayed for thrombolytic activity to determine the ability of natural products to promote lysis of blood clot. Addition of $100 \mu$ l streptokinase (SK), a positive control (30,000 I.U.) to the clots of human blood and subsequent incubation for 90 minutes at $37^{\circ} \mathrm{C}$ produced $66.77 \%$ lysis of the clot. On the other hand, distilled water treated as negative control, revealed a negligible lysis of clot (3.79\%). In this study, different extractives of $M$. arboreus and $P$. reticulatus demonstrated clot lysis activity ranging from $12.99 \%$ to $55.60 \%$ and $4.82 \%$ to $18.99 \%$, respectively. The pet-ether soluble fractions of crude methanolic extracts of $M$. arboreus and $P$. reticulatus revealed $55.60 \pm 0.48 \%$ and $18.99 \pm 0.84 \%$ clot lysis, respectively (Table 3 ).

The membrane stabilizing activity of $M$. arboreus and $P$. reticulatus extractives was also determined. Both significantly protected the lysis of human erythrocyte membrane induced by heat and hypotonic solution, as compared to the standard acetyl salicylic acid. In heat- and hypotonic solutioninduced conditions, the chloroform soluble partionates of $M$. arboreus inhibited $54.60 \pm 0.81 \%$ and $66.96 \pm 0.84 \%$ haemolysis of RBCs, respectively as compared to $57.06 \%$ and $72.79 \%$ inhibition by acetyl salicylic acid $(0.10 \mathrm{mg} / \mathrm{ml})$, respectively. The pet-ether soluble fraction of crude methanol extract of $P$. reticulatus demonstrated 57.51 $\pm 0.57 \%$ and $70.62 \pm 0.22 \%$ inhibition of hypotonic solution- and heat-induced hemolysis, respectively (Table 4).

It is clearly evident from the above findings that the leaves of $M$. arboreus have significant free radical scavenging, cytotoxic and thrombolytic properties. On the other hand, the leaves of $P$. reticulatus have significant membrane stabilizing activity. The plant also exhibited mild thrombolytic potential. Traditional healers of southern districts of Noakhali and Feni of Bangladesh use leaves and flowers of M. arboreus for skin diseases of hands ${ }^{19}$ while the stem of $P$. reticulatus is used in the treatment of diarrhea ${ }^{20}$, chiken pox $^{21}$ and dental carries. ${ }^{22}$ The findings of this study especially the low $\mathrm{LC}_{50}$ values in brine shrimp lethality bioassay justify the traditional uses of these two plant species. Therefore, both plants are potential candidates for further chemical investigations to isolate the bioactive molecules.

\section{ACKNOWLEDGEMENT}

The authors are grateful to the staffs of Dhaka University Saler Khan Herbarium for identification of the plant species

\section{REFERENCES}

1. Adamu, H.M., Abayeh, O.J., Agho, M.O., Abdullahi, A.L., Uba, A., Dukku, H.U. and Wufem, B.M. 2004. An ethnobotanical survey of Bauchi State herbal plants and their antimicrobial activity. J. Ethnopharmacol. 99, 1-4.

2. Rios, J.L. and Recio, M.C. 2005. Medicinal plants and antimicrobial activity. J. Ethnopharmacol. 100, 80- 84.

3. Cragg, G.M., Newman, D.J. and Snader, K.M. 1997. Natural products in drug discovery and development. J. Nat. Prod. 60, 52- 60 .

4. Chowdhury, J.A., Islam, M.S., Asifuzzaman, S. and Islam, M.K. 2009. Antibacterial and cytotoxic activity screening of leaf extracts of Vitex negundo (Fam: Verbenaceae). J. Pharm. Sci. Res. 1, 103-108.

5. Saikia, P. and Khan, M.L. 2011. Diversity of medicinal plants and their uses in homegardens of upper Assam, Northeast India. Asian J. Pharm. Biol. Res. 1, 296-309

6. Kumar, S., Sharma, S., Kumar, D., Kumar, T., Arya, R. and Kumar, K. 2012. Pharmacognostic study and antiinflammatory activity of Phyllanthus reticulatus Poir. Fruit. Asian Pac. J. Trop. Dis. S 332- 335.

7. Aswatha, R.H.N., Shreedhara, C.S., Falguni, P.G. and Sachin, B.Z. 2008. In vitro free radical scavenging potential of methanol extract of entire plant of Phyllanthus reticulatus Poir. Pharmacologyonline 2, 440-451.

8. Jamal, A.K., Yaacob, W.A. and Din, L.B. 2008. A chemical study on Phyllanthus reticulatus. J. Phys. Sci. 19, 45-50.

9. Lan, M.S., Ma, J.X., Tan, C.H., Wei, S. and Zhu, D.Y. 2010. Chemical constituents of Phyllanthus reticulates. Helv. Chim. Acta. 99, 2276-2280. 
10. Kaisar, M.A., Rahman, M.S., Rahman, M.Z., Hasan, C.M. and Rashid, M.A. 2011. A review on phytochemicals from some medicinal plants of Bangladesh. J. Phar. Nutri. Sci. 1, 87-95.

11. Sharmin, T., Islam, F., Kaisar, M.A., Uddin, M.G. and Rashid, M.A. 2012. Antioxidant, thrombolytic and cytotoxic activities of Picrasma javanica. Dhaka Univ. J. Pharm. Sci. 11, 71-74.

12. Sikder, M.A., Sharmin, T., Rahman, A.F.M.M., Haque, M.R., Rahman, M.S. and Rashid, M.A. 2013. Screenings of four medicinal plants of Bangladesh for bioactivities. Dhaka Univ. J. Pharm. Sci. 12, 59-62.

13. Van Wagenen, B.C., Larsen, R., Cardellina, J.H., Randazzo, D., Lidert, Z.C. and Swithenbank, C. 1993. Ulosantoin, a potent insecticide from the sponge Ulosa ruetzleri. J. Org. Chem. 58, 335-337.

14. Harbertson, J. and Spayd, S. 2006. Measuring phenolics in the winery. Am. J. Enol. Vitic. 57, 280-288.

15. Brand-Williams, W., Cuvelier, M.E. and Berset, C. 1995. Use of free radical method to evaluate antioxidant activity. Lebensm. Wiss. Technol. 28, 25-30.

16. Meyer, B.N., Ferringni, N.R., Puam, J.E., Lacobsen, L.B., Nichols, D.E. and McLaughlin, J.L. 1982. Brine shrimp: a convenient general bioassay for active constituents. Planta Med. 45, 31-32.

17. Prasad, S., Kashyap, R.S., Deopujari, J.Y., Purohit, H.J., Taori, G.M. and Daginawala, H.F. 2007. Effect of Fagonia arabica (Dhamasa) on in vitro thrombolysis. BMC Complement. Alternat. Med. 7:36 doi: 10.1186/1472-6882-736.
18. Omale, J. and Okafor, P.N. 2008. Comparative antioxidant capacity, membrane stabilization, polyphenols composition and cytotoxicity of the leaf and stem of Cissus multistriata. Afr. J. Biotechnol. 7, 3129-3133.

19. Rahmatullah, M., Mahmud, A.A., Rahman, M.A., Uddin, M.F., Hasan, M., Khatun, M.A., Bashar, A.B.M.A., Ahsan, S., Mou, S.M., Begum, R. and Jahan, R. 2011. An ethnomedicinal survey conducted amongst folk medicinal practitioners in the two southern districts of Noakhali and Feni, Bangladesh. Am. Eurasian J. Sustain. Agric. 5, 115-131.

20. Kabir, M.H., Hasan, N., Rahman, M.M., Rahman, M.A., Khan, J.A., Hoque, N.T., Bhuiyan, M.R., Mou, S.M., Jahan, R. and Rahmatullah, M. 2014. A survey of medicinal plants used by the Deb barma clan of the Tripura tribe of Moulvibazar district, Bangladesh. J. Ethnobiol. Ethnomed. 10, doi:10.1186/1746-4269-10-19

21. Mawla, F., Khatoon, S., Rehana, F., Jahan, S., Shelley, M.M.R., Hossain, S., Haq, W.M., Rahman, S., Debnath, K. and Rahmatullah, M. 2012. Ethnomedicinal plants of folk medicinal practitioners in four villages of Natore and Rajshahi districts, Bangladesh. Am. Eur. J. Sustain. Agric. 6, 406-416.

22. Rahman, M.A., Uddin, S.B. and Wilcock, C.C. 2007. Medicinal plants used by Chakma tribe in hill tracts districts of Bangladesh. Indian J. Trad. Knowl. 6, 508-517. 